\title{
Strain variability of the cell-free proteolytic activity of dairy propionibacteria towards $\beta$-casein peptides
}

\author{
Riwanon Lemée ${ }^{\mathrm{a}}$, Valérie Gagnaire ${ }^{\mathrm{b} *}$, Jean-Louis Maubois ${ }^{\mathrm{b}}$ \\ ${ }^{a}$ Standa-Industrie, 184, rue Maréchal-Gallieni, 14050 Caen cedex, France \\ ${ }^{b}$ Laboratoire de recherches de technologie laitière, Inra, 65, rue de Saint-Brieuc, \\ 35042 Rennes cedex, France
}

(Received 10 June 1997; accepted 23 October 1997)

\begin{abstract}
Strain selection of dairy propionibacteria is based on $\mathrm{CO}_{2}$, acetate and propionate production. However, another criterion such as proteolytic activity could be of industrial interest for selection of flavor ripening agents. Given that the propionibacteria are variously able to autolyse and that proteolytic activity is mainly intracellularly located, the proteolytic potential was evaluated on the cell-free extracts of 37 dairy propionibacteria strains. The substrate used to detect proteolytic activity was a tryptic/chymotryptic hydrolysate of $\beta$-casein. The evaluation was performed at a temperature of $30^{\circ} \mathrm{C}$ and $\mathrm{pH}$ of 5.7. The increase in the free $\mathrm{NH}_{2}$ groups over a $24 \mathrm{~h}$ period was monitored as well as the evolution of the reversed-phase chromatographic profiles. In addition, for 14 strains, the free amino acids released from the $\beta$-casein peptides were determined. All the strains were able to hydrolyze $\beta$-casein peptides. Difference of proteolytic activity was observed among and within the four dairy propionibacteria species. This variability was expressed more in terms of nature of the products released (peptides and free amino acids) than in terms of degree of proteolytic activity. From the results, a strain selection system may be developed using as substrate the tryptic/chymotryptic $\beta$-casein hydrolysate and as criteria the degree of hydrolysis at $24 \mathrm{~h}$ and the amount and the nature of free amino acids released by cellfree extracts. Such a selection will give useful data for cheesemakers, especially if characterization of autolytic ability in the cheese environment is also determined. (C) Inra/Elsevier, Paris.
\end{abstract}

\section{propionibacteria / proteolysis / peptide / free amino acid / selection}

Résumé - Souche dépendance de l'activité protéolytique intracellulaire de bactéries propioniques laitières sur un substrat laitier (hydrolysat de caséine $\beta$ ). La sélection des souches de bactéries propioniques est fondée sur la production de $\mathrm{CO}_{2}$, d'acétate et de propionate. Cependant, un autre critère tel que l'activité protéolytique pourrait présenter un intérêt industriel afin de sélectionner des souches susceptibles de produire des précurseurs de flaveurs. En tenant compte du fait que les bactéries propioniques possèdent une capacité variable à s'autolyser et que

\footnotetext{
* Correspondence and reprints. E-mail : gagnaire@labtechno.roazhon.inra.fr
} 
l'activité protéolytique est localisée principalement dans la fraction cytoplasmique de la bactérie, nous avons évalué le potentiel protéolytique d'extrait intracellulaire de 37 souches de bactéries propioniques. Le substrat utilisé pour tester l'activité de manière globale était un hydrolysat trypsique/chymotrypsique de caséine $\beta$. L'hydrolyse était réalisée à $30^{\circ} \mathrm{C}$ et à $\mathrm{pH} 5,7 . \mathrm{L}$ 'augmentation de la teneur en groupements $\mathrm{NH}_{2}$ libres était suivie sur 24 heures, ainsi que l'évolution des profils chromatographiques par analyse CLHP phase inverse. De plus, pour 14 souches, nous avons déterminé la composition en acides aminés libérés. Nous avons observé que toutes les souches étaient capables d'hydrolyser les peptides de la caséine $\beta$ avec une activité protéolytique différente selon les quatre espèces de bactéries propioniques mais également au sein d'une même espèce. Cette variabilité s'exprimait plus en terme de nature de produits libérés (peptides et acides aminés) qu'en terme d'intensité de la protéolyse. À partir de ces résultats, une sélection des souches peut être envisagée, en utilisant comme substrat l'hydrolysat trypsique/chymotrypsique de caséine $\beta$ et, comme critères, le degré d'hydrolyse à $24 \mathrm{~h}$ ainsi que la quantité et la nature des acides aminés libérés par les extraits intracellulaires. Une telle sélection pourrait donner d'utiles informations aux fromagers, d'autant plus si, en complément, la caractérisation des capacités autolytiques des souches en conditions fromagères est réalisée. (O) Inra/Elsevier, Paris.

\section{propionibactérie / protéolyse / peptide / acide aminé libre / sélection}

\section{INTRODUCTION}

Dairy propionibacteria species are mainly present in some fermented dairy products, particularly in hard cooked cheeses such as Gruyère and Emmental [4]. Their fermentation characteristics lead to typical flavor and aroma development but their involvement in the protein breakdown seems apparently low compared to that of the thermophilic lactic acid bacteria used as starters [33].

Various peptidase activities have been shown in the four dairy propionibacteria species (for review see [19]). They are mainly intracellularly located $[12,23,27$, 31]. Four of them identified in $P$. freudenreichii are supposed to play a major role in Swiss cheese flavor development: a proline iminopeptidase $[25,27]$, prolinase and prolidase [29] and two phenylalanine aminopeptidases [10]. The amino acids, Pro and Phe, are released at a high level during ripening and shown respectively as component participating to the sweetness and as a precursor of floral flavor of the cheese $[3,6,17,18]$. The release of intracellular peptidase activities in cheese curd during ripening requires evidently an autolytic mechanism induced in propionibacteria cells, either physiologically or by environmental conditions. Such an autolysis was recently observed under in vitro conditions $[20,21,23,24]$ and in Emmental (Valence F., personal communication),

The aim of this work was to evaluate the cell-free proteolytic activity of 37 propionibacteria strains belonging to four different species, 15 of which were of industrial origin. This potential was determined on a substrate related to that encountered in cheese aqueous phase. Our choice was a tryptic/chymotryptic $\beta$-casein hydrolysate because: i) during Swiss-type cheese ripening, the main peptides arose from $\beta$-casein $[1,2]$; ii) the substrate specificity of trypsin was equivalent to that of plasmin, which plays a major role in primary hydrolysis of para-casein network and iii) the chymotrypsin specificity towards $\mathrm{C}$-terminus of amino acid residues such as Phe ${ }_{52}, \mathrm{Leu}_{58}, \mathrm{Gln}_{72}$ and Met $_{93},[26]$ allowed to have cleavage at 
sites which have been identified in Swisstype cheese $[1,2]$.

\section{MATERIALS AND METHODS}

\subsection{Bacterial strains and growth conditions}

The strains, obtained from the CNRZ collection (Inra, 78352 Jouy-en-Josas, France), the CIP collection (Institut Pasteur, 75015 Paris, France), our own collection TL (Inra, 35042 Rennes, France) and from commercial origin (table I) were stored at $-80^{\circ} \mathrm{C}$ in yeast extract lactate (YEL) broth [22] containing $15 \%(\mathrm{v} / \mathrm{v})$ glycerol. Two transfers at $1 \%(\mathrm{v} / \mathrm{v})$ in YEL broth during $48 \mathrm{~h}$ at $30^{\circ} \mathrm{C}$ were performed before the cells were grown statically in $1 \mathrm{~L}$ YEL broth at $30^{\circ} \mathrm{C}$. Growth was monitored at $650 \mathrm{~nm}\left(\mathrm{OD}_{650}\right)$ using a model DU 7400 spectrophotometer (Beckman Instruments Inc., Fullerton, CA, U.S.A.).

\subsection{Preparation of the cell-free extracts}

Cells harvested in early exponential growth phase (at an $\mathrm{OD}_{650}$ of 1 ; when the $\mathrm{pH}$ reached 6.0 , corresponding to about $30 \mathrm{~h}$ of incubation) were washed twice with cold sterile distilled water, and recovered by centrifugation for $30 \mathrm{~min}$ at $5000 \mathrm{~g}$, at $4{ }^{\circ} \mathrm{C}$. The cell pellets were stored at $-20^{\circ} \mathrm{C}$ in order to render the cells fragile before mechanical disruption at $138 \mathrm{MPa}$ in a refrigerated French pressure cell (SLM-Aminco, Urbana, IL, U.S.A.) under the conditions described by Lemée et al. [21]. Undisrupted cells and cell debris were removed by centrifugation at $3000 \mathrm{~g}$ for $30 \mathrm{~min}$, at $4{ }^{\circ} \mathrm{C}$

Table I. Origin of the strains used in this study.

Tableau I. Origine des souches utilisées dans cette étude.

\begin{tabular}{lll}
\hline Species & Source & Strains \\
\hline
\end{tabular}

P. freudenreichii subsp. freudenreichii:

$\begin{array}{cl}\begin{array}{c}\text { industrial strains } \\ \text { TL }\end{array} & \text { A, B, C, D, E, F, G, H, I, J, K, L, M, N, O } \\ & \text { TL 511, TL 213, TL 230, TL 234, TL 503, } \\ & \text { TL 501, TL 504A, TL 504B, TL 512, TL 510A, } \\ \text { CIP } & \text { TL 510B, TL 510C } \\ \text { CNRZ } & \text { CIP 5932, CIP 103026 } \\ \text { CNRZ 89 }\end{array}$

P. freudenreichii subsp. shermanii:

$\begin{array}{lll} & \text { CIP } & \text { CIP 103027 } \\ \text { CNRZ } & \text { CNRZ 725, CNRZ 726 } \\ \text { P. jensenii } & \text { CIP } & \text { CIP 103028 } \\ & \text { TL } & \text { TL 222 } \\ \text { P. thoenii } & \text { CIP } & \text { CIP } 103029 \\ \text { P. acidipropionici } & \text { TL } & \text { TL } 249\end{array}$

TL (Collection of the Laboratoire de recherches de technologie laitière, Inra Rennes, France); CNRZ (Collection of INRA, Jouy-en-Josas, France); CIP (Collection of the Institut Pasteur, Paris, France). A to O: Industrial strains.

TL (collection du Laboratoire de recherches de technologie laitière, Inra Rennes, France) ; CNRZ (Collection de l'Inra, Jouy-en-Josas, France); CIP (collection de l'Institut Pasteur, Paris, France). A à O : souches commerciales. 
and the collected supernatant was filtered $(0.45 \mu \mathrm{m}$, Sartorius, Laboratoires Humeau, La Chapelle S/Erdre, France), distributed in tubes $(1 \mathrm{~mL})$, and stored at $-20^{\circ} \mathrm{C}$ until use. For all the strains, the protein content of the cell-free extracts was determined according to the microprocedure of Bradford (Biorad SA, Ivrysur-Seine, France) using bovine serum albumin (Sigma, Saint-Quentin-Fallavier, France) as standard. The protein content varied in the range $2.9 \pm 0.8 \mathrm{mg}$ eq. BSA per $\mathrm{mL}$ of cellfree extracts.

\subsection{Preparation of the $\beta$-casein hydrolysate}

$\beta$-Casein, kindly supplied by Eurial Poitouraine (Nantes, France), at $10 \mathrm{~g} / \mathrm{L}$ in sterile distilled water, was hydrolyzed by a mixture of trypsin $(5000 \mathrm{~K}$, Novo Industry A/S, Copenhagen, Denmark) and chymotrypsin (Sigma), both at an enzyme/substrate ratio of $1 / 1000$ (w/w), at $\mathrm{pH} 7.2$ maintained constant by adding $\mathrm{NaOH} 0.5 \mathrm{~mol} / \mathrm{L}$ for $3 \mathrm{~h}$ at $37^{\circ} \mathrm{C}$. Then the enzymes were inactivated by heating at $80^{\circ} \mathrm{C}$ for $20 \mathrm{~min}$. The $\beta$-casein hydrolysate was freeze-dried (model CS 10-08, CIRP-Serail, Argenteuil, France) and stored at $4{ }^{\circ} \mathrm{C}$ until use.

The degree of $\beta$-casein hydrolysis was about $16 \%$, determined from the ratio of the number of $\mathrm{NH}_{2}$ groups released after the tryptic/chymotryptic hydrolysis to the total number of $\mathrm{NH}_{2}$ groups of the initial $\beta$-casein. The $\mathrm{NH}_{2}$ groups were detected by the reaction with fluorodinitrobenzene (FDNB) [15] using methionine (Sigma) as standard. This was in agreement with the theoretical peptide bond specificities of trypsin and chymotrypsin reported by Pélissier [26] and the number of final peptides (i.e., 28) susceptible to be produced with both enzymes.

\subsection{Hydrolysis of $\beta$-casein peptides by the cell-free extracts}

Cell-free extracts, $550 \mu \mathrm{g}$ protein adjusted to $500 \mu \mathrm{L}$ with sterile distilled water, were added to $3.5 \mathrm{~mL}$ of $\beta$-casein peptide solution ( $0.8 \mathrm{mg} \beta$-casein hydrolysate per $\mathrm{mL}$ of sodium phosphate buffer $50 \mathrm{mmol} / \mathrm{L}, \mathrm{pH}$ 5.7). Duplicate samples $(300 \mu \mathrm{L})$, withdrawn at zero time and after $0.5,1,3$ and $24 \mathrm{~h}$ of incubation at $30{ }^{\circ} \mathrm{C}$ were inactivated by heating at $100{ }^{\circ} \mathrm{C}$ in a water bath for $10 \mathrm{~min}$.

\subsection{Measurement of the total proteolytic activity of the cell-free extracts}

The proteolytic activity of the cell-free extracts was determined by analyzing the increase in $\mathrm{N}$-terminal $\mathrm{NH}_{2}$ groups of the $\beta$-casein peptides by reaction with fluorodinitrobenzene (FDNB) according to the method of Ghuysen et al. [15] and using methionine (Sigma) as standard. The results were expressed according to two parameters: i) the initial rate of free amino groups increase; and ii) the degree of proteolysis after $24 \mathrm{~h}$. The initial rate was calculated during the first $30 \mathrm{~min}$ of incubation and was expressed in $\mu \mathrm{mol}$ equivalent Met per min, for one mg of cell-free extract protein. The degree of proteolysis corresponded to the difference between the $\mathrm{NH}_{2}$ values determined at $24 \mathrm{~h}$ and at zero time and was expressed in $\mu \mathrm{mol}$ equivalent Met per $\mathrm{mL}$ of solution for a defined quantity of intracellular protein in the tested fraction. $\beta$-casein hydrolysate was incubated as a control as well as the cell-free extract of the strains, and the heat-treated cell-free extract mixed with the $\beta$-casein peptides.

\subsection{Chromatographic analysis}

$\beta$-casein peptide hydrolysates were acidified with $10 \%(\mathrm{v} / \mathrm{v})$ trifluoroacetic acid (TFA, Pierce, Touzart et Matignon, Vitry-sur-Seine, France) to a final concentration of $0.1 \%(\mathrm{v} / \mathrm{v})$, and passed through a filter of $0.45 \mu \mathrm{m}$ pore size (Millex-HV ${ }_{13}$, Millipore, Saint Quentin-enYvelines, France). One hundred $\mu \mathrm{L}$ were injected, without sample dilution, onto the analytical reverse-phase Lichrospher $100 \mathrm{RP}_{18}$ column (124 x 4 mm I.D.; Merck), equilibrated at a flow rate of $1 \mathrm{~mL} / \mathrm{min}$ and at $40{ }^{\circ} \mathrm{C}$ with buffer A containing $1.06 \mathrm{~mL} / \mathrm{L}$ TFA in water of HPLC grade (Millipore). The linear gradient was performed from 0 to $40 \%$ buffer B containing $1 \mathrm{~mL} / \mathrm{L}$ TFA, $800 \mathrm{~mL} / \mathrm{L}$ acetonitrile (Merck) and $200 \mathrm{~mL} / \mathrm{L}$ water in $50 \mathrm{~min}$, followed by 40 to $80 \%$ buffer B in $20 \mathrm{~min}$. The absorbance was monitored at $214 \mathrm{~nm}$ with a 
Spectra Physics SP 8490 UV detector (Thermo Separation Products, Les Ulis, France).

\subsection{Analysis of the free amino acids}

For 14 strains, the peaks eluted during the first $10 \mathrm{~min}$ of the $24 \mathrm{~h}$ RP-HPLC separations were collected in two distinct fractions named $\mathrm{A}$ and $\mathrm{B}$ as shown in figure 2 . The samples, after freeze-drying were analyzed for their free amino acid content. They were resuspended in water of HPLC grade and directly derivatized with phenylisothiocyanate (Pierce, Touzart et Matignon). Quantitative analysis of the amino acid derivatives was performed by RP-HPLC on a Pico-Tag $\mathrm{C}_{18}$ column $(150 \times 3.9 \mathrm{~mm}$ I.D.; Waters, Saint-Quentin-en-Yvelines, France) according to Bidlingmeyer et al. [5]. Two controls were used: i) the $\beta$-casein peptides alone $(0.7 \mathrm{mg} / \mathrm{mL})$; and ii) a sample containing the heat-treated intracellular extract of CIP 103027 mixed with the $\beta$-casein peptides.

\section{RESULTS}

\subsection{Time course of the $\beta$-casein peptide hydrolysis}

\subsubsection{Quantitative evaluation}

Increase versus time of released $\mathrm{NH}_{2}$ groups from $B$-casein peptides by cell-free extracts obtained from the five typical dairy propionibacteria species and subspecies are shown in figure 1. No free amino group increase indicating no peptidase activity was observed in the control experiment. Activities were different in two aspects: initial rate and degree reached after $24 \mathrm{~h}$ hydrolysis. The highest peptidase activity was observed with $P$. freudenreichii subsp shermanii CIP103027: initial rate determined for the first $30 \mathrm{~min}$ was $11.610^{-3} \mu \mathrm{mol}$ eq. $\mathrm{Met} / \mathrm{min}$ for $1 \mathrm{mg}$ intracellular protein and degree of hydrolysis at $24 \mathrm{~h}, 1.86 \mu \mathrm{mol}$ eq. Met $/ \mathrm{mL}$. P. thoenii CIP103029 and P. freudenreichii subsp. freudenreichii CIP103026 cell-free extracts had comparable initial rates and degree of hydrolysis whereas $P$. acidipropionici TL249 cellfree extracts showed practically no activity during the first $30 \mathrm{~min}$ and then a degree of hydrolysis close to that of $P$. jensenii CIP103028, i.e., somewhat below the other strains.

\subsubsection{Qualitative evaluation}

The more characteristic RP-HPLC-profiles obtained after $24 \mathrm{~h}$ hydrolysis with the cell-free extracts of the four species of propionibacteria are represented in figure 2 . Initially, the $\beta$-casein hydrolysate contained 28 main peaks, numbered 1 to 28 . Peaks $4,5,12,13,22,25$ and 26 completely disappeared for all the strains. Chromatographic profiles resulting from incubation with $P$. acidipropionici and P. thoenii extracts showed absence of peak 14 to 18 and 27 and 28, respectively. Peak 19 disappeared for both subspecies of $P$. freudenreichii. On the other hand, new peaks, numbered 29 to 35 , appeared as a consequence of hydrolysis. Among them, peaks 29,30 and 35 were present for all the species. In contrast, peak 31 was absent from the chromatographic profiles of $P$. freudenreichii including both subspecies, peak 32 from that of $P$, thoenii, peak 33 from those of $P$, acidipropionici and P. freudenreichii including both subspecies and peak 34 from that of $P$. jensenii. A specific 'fingerprint' is therefore observed for each of the four dairy propionibacteria species through the proteolysis of the tested $\beta$-casein hydrolysate by their cell-free extracts and there was no difference between two subspecies of $P$. freudenreichii.

\subsection{Comparison of the proteolytic activity between the 37 strains}

Figure 3 summarizes the proteolytic activity of the 37 tested strains of propionibacteria according to the initial rate (figure $3 a$ ) and the degree of hydrolysis 


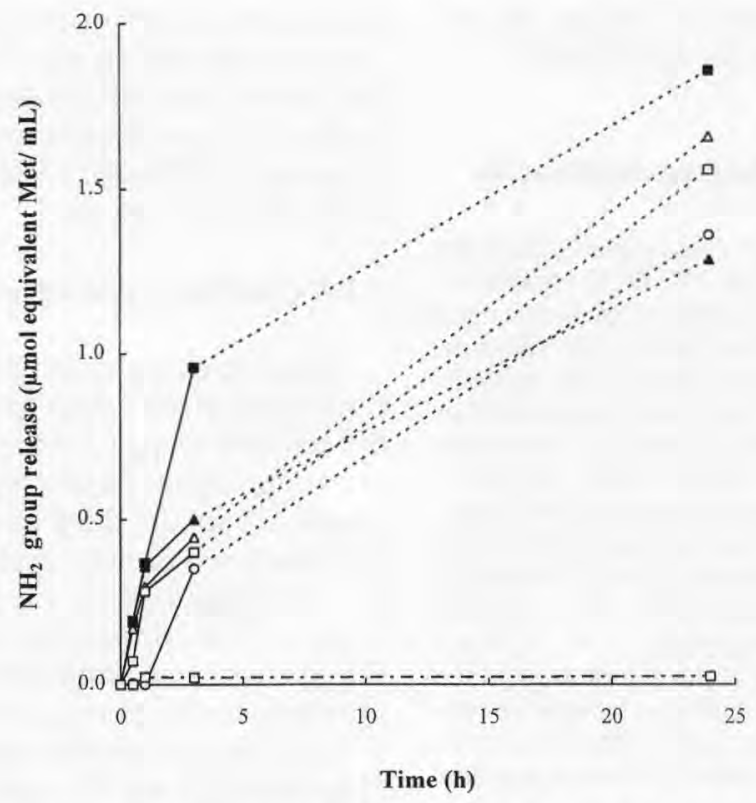

Figure 1. Time course of the $\beta$-casein peptide hydrolysis by the cell-free extract of the four species of propionibacteria: Propionibacterium freudenreichii subsp, freudenreichii CIP103026 $(\Delta)$ and subsp. shermanii CIP103027 ( $)$, P. jensenii CIP103028 ( $\Delta$ ), P. thoenii CIP103029 ( $\square$ ), and $P$. acidipropionici TL249 (O). The proteolytic activity is determined by the $\mathrm{NH}_{2}$ group release and expressed in $\mu \mathrm{mol}$ eq. Met $/ \mathrm{mL}$. The hydrolysis was performed at $30^{\circ} \mathrm{C}$ with $137.5 \mu \mathrm{g} / \mathrm{mL}$ intracellular protein for $0.7 \mathrm{mg}$ of freeze-dried $\beta$-casein peptides $/ \mathrm{mL}$ of $50 \mathrm{mmol} / \mathrm{L}$ sodium phosphate buffer at $\mathrm{pH}$ 5.7. Incubation of the $\beta$-casein peptides, without enzyme extract is represented by - - $\cdot \square-\cdot \cdot$. Peptide hydrolysis evolution between 3 and $24 \mathrm{~h}$ is schematically represented by dashed lines.

Figure 1. Évolution au cours du temps de l'hydrolyse des peptides de la caséine $\beta$ par les extraits intracellulaires de souches de bactéries propioniques: Propionibacterium freudenreichii subsp. freudenreichii CIP103026 ( $\Delta$ ) et subsp. shermanii CIP103027 ( $)$ ), P. jensenii CIP103028 ( $\boldsymbol{\Delta}$ ), $P$. thoenii CIP103029 ( $\square$ ), et $P$. acidipropionici TL249 (O). L'activité protéolytique était dosée par la libération des groupements $\mathrm{NH}_{2}$ et exprimée en $\mu \mathrm{mol}$ eq. Met/mL. Les conditions d'hydrolyse étaient les suivantes : les extraits intracellulaires $(137,5 \mu \mathrm{g}$ eq. BSA $/ \mathrm{mL})$ étaient incubés à $30^{\circ} \mathrm{C}$ en présence de $0,7 \mathrm{mg}$ de peptides de caséine $\beta$ lyophilisés $/ \mathrm{mL}$ de tampon phosphate de sodium $50 \mathrm{mmol} / \mathrm{L}$ à $\mathrm{pH} 5,7$. L'incubation des peptides de la caséine $\beta$ en l'absence d'extraits intracellulaires est représentée par - - $-\square \cdot-\cdot$. L'évolution de la protéolyse des peptides entre 3 et $24 \mathrm{~h}$ est représentée schématiquement par un trait en pointillés.

after 24 h (figure $3 b$ ). It appears clearly from this figure that there was no high correlation between the two enzymatic parameters for classifying the strains. Some $P$. freudenreichii strains (A, B, C, CNRZ 726, TL234, TL230 and TL501), one of $P$. acidipropionici (TL249) and one of $P$. jensenii (TL222) showed no evidence of peptide bond cleavage within the first
$30 \mathrm{~min}$, however, large variations in the degree of hydrolysis at $24 \mathrm{~h}$ were observed between them, from the lowest $P$. jensenii TL222 with $1.1 \mu \mathrm{mol}$ eq. Met $/ \mathrm{mL}$ to a value close to the highest $P$. freudenreichii TL230 with $1.70 \mu \mathrm{mol}$ eq. Met $/ \mathrm{mL}$. The initial rate of proteolysis varied in general from 0 to about $1210^{-3}$ $\mu \mathrm{mol}$ eq. Met $/ \mathrm{min}$ for one $\mathrm{mg}$ intracellular 


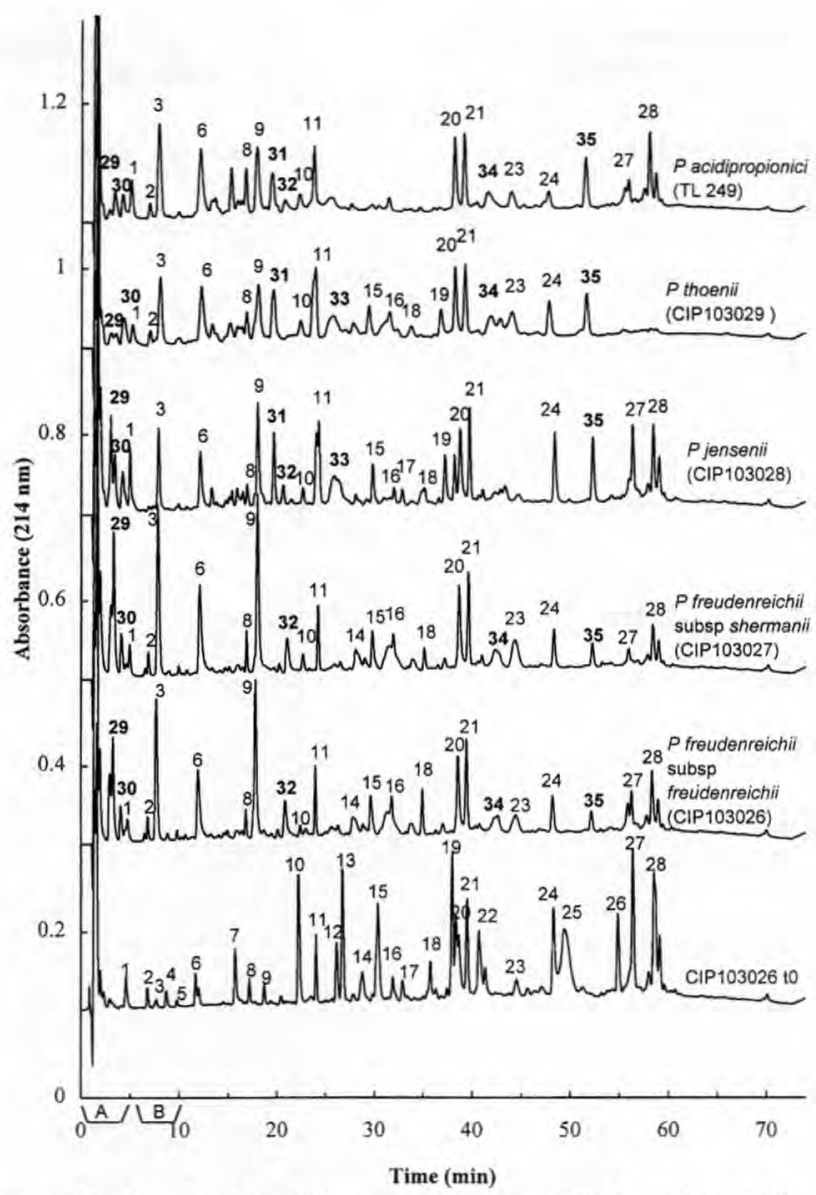

Figure 2. Comparison between the $24 \mathrm{~h}$ reversed-phase-HPLC profiles of the $\beta$-casein peptides hydrolyzed by the cell-free extracts of the four species of propionibacteria: Propionibacterium freudenreichii subsp. freudenreichii CIP103026 and subsp. shermanii CIP103027, P jensenii CIP103028, P. thoenii CIP103029 and $P$. acidipropionici TL249. These profiles were obtained from hydrolysis performed under the same conditions as described in the legend to figure 1. Peaks, initially present in the RP-HPLC profile of the $\beta$-casein peptides at $t=0$, were numbered 1 to 28 and the new peaks produced during hydrolysis were numbered 29 to 35 . The RP-HPLC profile of the $\mathrm{t}=0$ sample (CIP103026), corresponds to the reaction mixture of the heat-treated cell-free extract of the CIP103026 strain and the $\beta$-casein peptides, collected at zero time of incubation. A and B correspond to the fractions collected for amino acid analyses of 14 strains.

Figure 2. Comparaison des profils chromatographiques (RP-HPLC) obtenus après 24 heures d'hydrolyse des peptides de caséine $\beta$ par les extraits intracellulaires de quatre espèces de bactéries propioniques : $P$. freudenreichii subsp. freudenreichii CIP103026 et subsp. shermanii CIP103027, P. jensenii CIP103028, $P$. thonii CIP103029 et $P$. acidipropionici TL249. Les conditions d'hydrolyse correspondaient à celles décrites sur la figure 1. Les pics présents initialement dans le profil RP-HPLC des peptides de caséine $\beta$ à $t=0$ sont numérotés de 1 à 28 et les nouveaux pics, produits pendant l'hydrolyse, de 29 à 35 . Le chromatogramme du témoin noté CIP103026 to, correspond au mélange réactionnel suivant : l'extrait intracellulaire de la souche $P$. freudenreichii CIP103026 inactivé par la chaleur était ajouté aux peptides de la caséine $\beta$, et prélevé au temps $\mathrm{t}=0$. A et $\mathrm{B}$ correspondent aux fractions collectées pour l'analyse d'acides aminés réalisée sur 14 souches. 

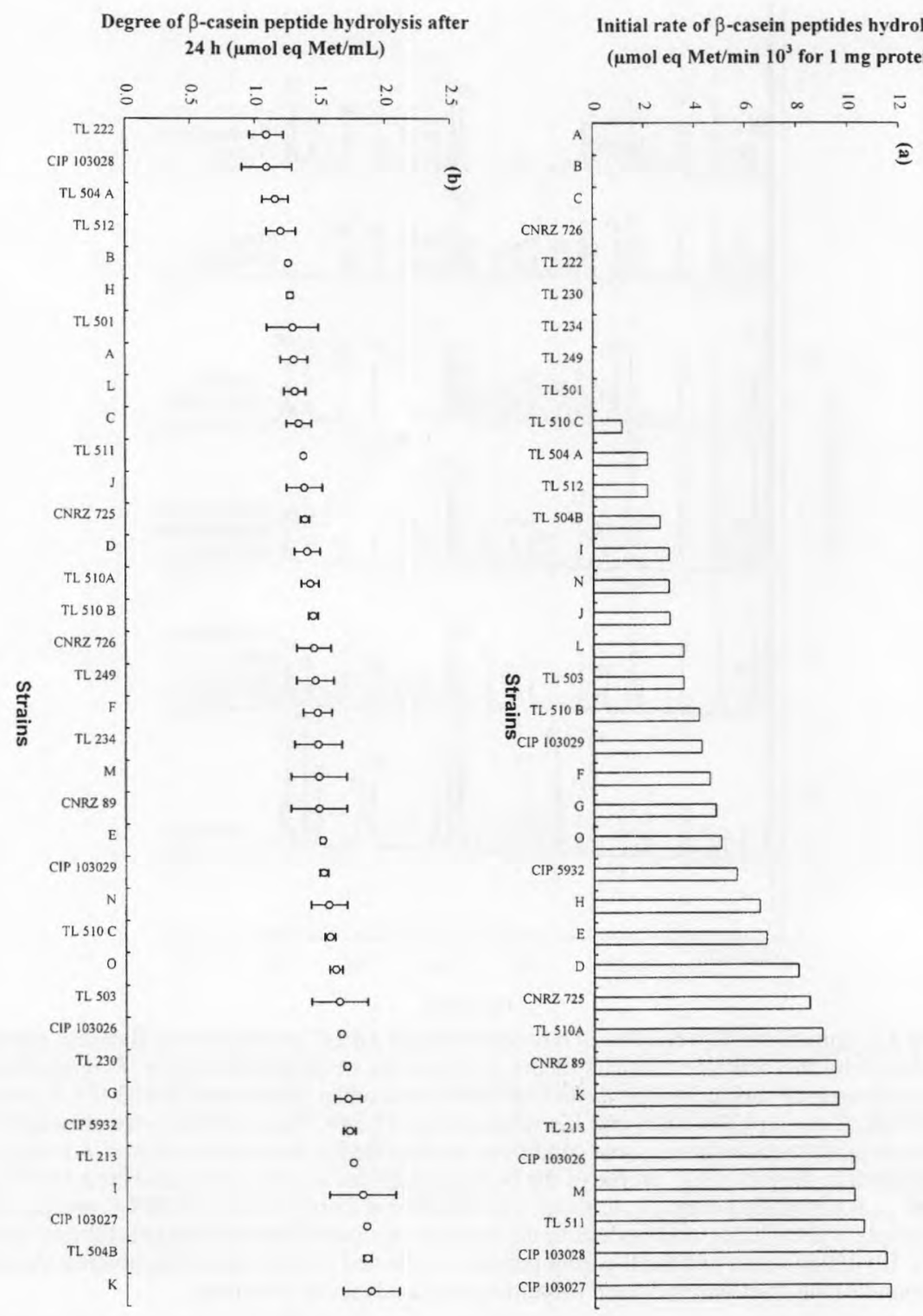

Figure 3. Comparison between the cell-free extracts of the 37 strains of propionibacteria of the initial rates of the $\beta$-casein peptide hydrolysis determined for the first $30 \mathrm{~min}$ (a) and the degree of hydrolysis obtained after $24 \mathrm{~h}$ of incubation (b). The enzymatic reaction was performed as described in the legend to figure 1 . These results are the average of, at least, two experiments. The average error percentage for the initial rates was $23 \%$.

Figure 3. Comparaison sur les 37 extraits intracellulaires de bactéries propioniques de la vitesse initiale d'hydrolyse des peptides de la caséine $\beta$, mesurée pendant les 30 premières min (a) et du degré d'hydrolyse après 24 heures d'incubation (b). Les conditions d'hydrolyse correspondaient à celles décrites sur la figure 1. Les résultats rendent compte de la moyenne de deux expérimentations au minimum. Le pourcentage d'erreur moyen sur les vitesses initiales était de $23 \%$. 
protein, whereas the degree of hydrolysis in $24 \mathrm{~h}$ varied between 1.1 and $1.89 \mu \mathrm{mol}$ eq. Met $/ \mathrm{mL}$.

From the data on degree of hydrolysis and by taking into account a $14 \%$ value as standard deviation of the experiment, only nine strains could be considered as having different proteolytic activities. They could be classified into two distinct groups: one containing five strains among the $P$. freudenreichii subspecies (TL213, I, $\mathrm{K}$, TL504B and CIP103027) with degree of hydrolysis more than $1.75 \mu \mathrm{mol}$ eq. Met $/ \mathrm{mL}$ and the other containing two strains from $P$. jensenii (CIP103028 and TL222), and two from $P$. freudenreichii subsp. freudenreichii (TL504A and TL512) with degree of hydrolysis less than $1.20 \mu \mathrm{mol} \mathrm{eq}$. Met $/ \mathrm{mL}$.

\subsection{Free amino acids after $24 \mathrm{~h}$ hydrolysis of the $\beta$-casein peptides}

In order to evaluate more closely the peptidase activities of the strains, free amino acids which were presumably eluted in fractions $\mathrm{A}$ and $\mathrm{B}$ in figure 2 during the first $10 \mathrm{~min}$ of the RP-HPLC profiles, were collected and analyzed for 14 strains. The results are presented in table II.

The $\beta$-casein hydrolysate, analyzed as a control, only contained detectable traces of Pro and Lys, in agreement with the specificities of both enzymes used, trypsin and chymotrypsin [26]. The heat-treated cell-free extract of $P$. freudenreichii subsp. shermanii CIP103027 mixed with the $\beta$-casein peptides, was checked at $\mathrm{t}=0$ and $\mathrm{t}=24 \mathrm{~h}$ as a second control. Presence of Glx, Pro, Thr and Val was observed in amounts comparable to those of Rolin et al. [30] for the intracellular fraction of this strain.

All the strains generated free amino acids, ranging from $7 \%$ of the total amino acid content of the $\beta$-casein for $P$. jensenii
TL222 (corresponding to the release of 14.9 amino acid residues) to $24 \%$ (i.e., 49.5 amino acid residues) for $P$. freudenreichii subsp. shermanii CIP103027. Some amino acids were not produced by all the strains. Asx was released only by extracts of $P$. freudenreichii subsp. freudenreichii $\mathrm{H}, \mathrm{K}$, and CIP5932, P. jensenii CIP103028 and $P$. thoenii CIP103029. Gly was not produced by $P$ freudenreichii subsp. freudenreichii CIP103026 and subsp. shermanii CIP103027 and by P. acidipropionici TL249. Ile in fraction A was absent with $P$. freudenreichii subsp. freudenreichii CIP5932, $\mathrm{K}$ and subsp. shermanii CNRZ 725 and with $P$. jensenii CIP103028 and TL222. This last strain did not release Ser, Arg, His and Met.

From the total amount of the free amino acids released and expressed in $\mu \mathrm{mol} / \mathrm{L}$, the 14 strains can be classified roughly into three groups: the first group with the highest amount over $1100 \mu \mathrm{mol} / \mathrm{L}$ contains the strains from $P$. freudenreichii subspecies (CIP103027, H, M, CIP5932, $\mathrm{K}$ ) and $P$. jensenii CIP103028; the second group $900-1000 \mu \mathrm{mol} / \mathrm{L}$ contains $P$. freudenreichii subsp. freudenreichii TL503, $\mathrm{J}$ and A, $P$ acidipropionici TL249 and $P$. thoenii CIP103029, and the remaining strains in the third group with values below $800 \mu \mathrm{mol} / \mathrm{L}$, with $P$. freudenreichii subspecies CIP103026 and CNRZ 725 and P. jensenii TL222.

Inside the $P$. jensenii species, we noted that the strains TL222 and CIP103028 previously shown as having similar degree of hydrolysis, were quite different in amino acid release, i.e., 1189 and $435 \mu \mathrm{mol} / \mathrm{L}$ for CIP103028 and TL222, respectively. The nature of the amino acids released also differed. In $P$. freudenreichii species, differences between degree of hydrolysis and amino acid release was also shown. In P. freudenreichii subsp. shermanii strain, CIP103027 has the highest degree of hydrolysis and release of free amino acids compared to strain CNRZ725. 
Table II. Analysis of the free amino acids (AA) released after 24 hours of $\beta$-casein peptide hydrolysis by the cell-free extracts of 14 propionibacteria strains.

Tableau II. Composition en acides aminés libres obtenus après 24 heures d'hydrolyse des peptides de la caséine $\beta$ par les extraits intracellulaires de

14 souches de bactéries propioniques.

\begin{tabular}{|c|c|c|c|c|c|c|c|c|c|c|c|c|c|c|c|c|c|}
\hline \multirow{2}{*}{\multicolumn{2}{|c|}{$\begin{array}{l}\text { Theoretical } \\
n^{\circ} \text { of AA } \\
\text { in } \beta \text {-casein }\end{array}$}} & $\begin{array}{c}\beta \text {-casein } \\
\text { peptides } \\
\text { control }\end{array}$ & $\begin{array}{c}\text { CIP } \\
103027 \\
\text { heat- } \\
\text { treated } \\
0 \mathrm{~h} / \mathrm{t} 24 \mathrm{~h}^{1}\end{array}$ & $\underset{103027}{\text { CIP }}$ & $\mathrm{H}$ & M & $\begin{array}{l}\text { CIP } \\
5932\end{array}$ & $\mathrm{~K}$ & $\begin{array}{c}\text { CIP } \\
103028\end{array}$ & $\begin{array}{c}\text { TL } \\
249\end{array}$ & $\begin{array}{c}\text { CIP } \\
103029\end{array}$ & $\begin{array}{r}\mathrm{TL} \\
503\end{array}$ & J & A & $\begin{array}{c}\text { CIP } \\
103026\end{array}$ & $\begin{array}{l}\text { CNRZ } \\
725\end{array}$ & $\begin{array}{l}\mathrm{TL} \\
222\end{array}$ \\
\hline & & \multicolumn{16}{|c|}{ Free amino acids ${ }^{2}$} \\
\hline \multicolumn{18}{|l|}{ Fraction $A^{3}$} \\
\hline Asx & 9 & - & - & - & 1.2 & - & 1.0 & 1.2 & 1.0 & - & 0.7 & - & - & - & - & - & - \\
\hline Glx & 39 & - & $2.1 / 2.4$ & 4.8 & 5.3 & 5.7 & 6.2 & 4.7 & 5.7 & 2.2 & 2.0 & 2.3 & 3.0 & 2.3 & 2.6 & 1.8 & 1.3 \\
\hline Pser + Ser & 16 & - & - & 2.3 & 1.7 & 1.7 & 1.9 & 2.3 & 1.5 & 1.2 & 0.8 & 1.0 & 1.2 & 1.0 & 1.1 & 0.7 & - \\
\hline Gly & 5 & - & - & - & 2.1 & 2.2 & 1.7 & 2.4 & 2.7 & - & 1.3 & 1.5 & 1.6 & 2.0 & - & 1.0 & 0.9 \\
\hline His & 5 & - & - & 2.0 & 1.9 & 2.1 & 2.0 & 1.7 & 1.8 & 1.5 & 1.5 & 1.3 & 1.4 & 1.4 & 1.2 & 1.1 & - \\
\hline Arg & 4 & - & - & 2.3 & 1.8 & 1.7 & 1.2 & 1.4 & 2.6 & 1.6 & 1.4 & 0.8 & 1.5 & 1.1 & 1.1 & 0.9 & - \\
\hline Thr & 9 & - & $0.9 / 1$ & 3.8 & 3.0 & 2.7 & 3.6 & 2.4 & 3.6 & 2.6 & 2.4 & 1.7 & 2.4 & 1.7 & 1.7 & 1.5 & 0.8 \\
\hline Ala & 5 & - & - & 3.2 & 3.0 & 2.6 & 3.2 & 2.3 & 5.1 & 2.7 & 2.2 & 1.9 & 2.3 & 2.2 & 1.6 & 1.7 & 1.3 \\
\hline Pro & 35 & 0.1 & $2.9 / 3.3$ & 5.3 & 4.3 & 3.7 & 3.5 & 4.4 & 4.5 & 2.7 & 2.1 & 3.4 & 2.9 & 4.4 & 2.7 & 1.4 & 1.9 \\
\hline Val & 19 & - & $0.7 / 0.7$ & 5.5 & 4.2 & 4.5 & 4.8 & 4.2 & 4.1 & 4.0 & 3.6 & 3.2 & 3.2 & 3.1 & 3.3 & 2.0 & 1.6 \\
\hline Met & 6 & - & - & 2.5 & 1.6 & 1.9 & 2.2 & 1.6 & 1.5 & 1.6 & 2.1 & 1.4 & 1.2 & 1.4 & 1.1 & 0.9 & - \\
\hline Ile & 10 & - & - & 2.2 & 1.8 & 1.7 & - & - & - & 1.4 & 1.0 & 1.0 & 0.8 & 0.9 & 0.6 & - & - \\
\hline Lys & 11 & 0.2 & $0 / 0.7$ & 3.9 & 4.7 & 4.3 & 3.7 & 3.7 & 5.8 & 3.0 & 3.7 & 2.5 & 3.1 & 2.5 & 2.2 & 2.0 & 1.7 \\
\hline \multicolumn{18}{|l|}{ Fraction B : } \\
\hline Tyr & 4 & - & - & 2.3 & 1.9 & 1.5 & 1.3 & 1.7 & 1.0 & 1.7 & 1.0 & 1.9 & 1.5 & 1.7 & 1.3 & 1.2 & 0.7 \\
\hline $\mathrm{Ile}+\mathrm{Leu}$ & 32 & - & - & 6.9 & 4.9 & 4.5 & 4.1 & 5.1 & 4.1 & 5.2 & 4.5 & 5.7 & 4.4 & 4.0 & 4.6 & 2.9 & 3.2 \\
\hline Phe & 9 & - & - & 2.8 & 2.4 & 1.9 & 1.9 & 2.3 & 1.8 & 2.6 & 2.0 & 2.3 & 1.5 & 2.0 & 1.5 & 1.3 & 1.7 \\
\hline $\begin{array}{l}\text { Total } \\
(\mu \mathrm{mol} / \mathrm{L})\end{array}$ & 209 & & & $\begin{array}{r}49.5 \\
(1445)\end{array}$ & $\begin{array}{r}46.0 \\
(1344)\end{array}$ & $\begin{array}{r}42.6 \\
(1245)\end{array}$ & $\begin{array}{c}42.2 \\
(1233)\end{array}$ & $\begin{array}{r}41.3 \\
1207)\end{array}$ & $\begin{array}{r}40.7 \\
(1189)\end{array}$ & $\begin{array}{r}33.9 \\
(991)\end{array}$ & $\begin{array}{l}32.2 \\
(941)\end{array}$ & $\begin{array}{r}31.9 \\
(932)\end{array}$ & $\begin{array}{l}31.9 \\
(932)\end{array}$ & $\begin{array}{r}31.7 \\
(926)\end{array}$ & $\begin{array}{c}26.7 \\
(780)\end{array}$ & $\begin{array}{r}20.4 \\
(596)\end{array}$ & $\begin{array}{r}14.9 \\
(435)\end{array}$ \\
\hline
\end{tabular}

'Strain designations are referred to table $I$. The cell-free extract of CIP 103027 was heat-treated $\left(100{ }^{\circ} \mathrm{C}, 10 \mathrm{~min}\right)$ before adding to the $\beta$-casein peptide solution. ${ }^{2} \mathrm{The}$ free amino acids are expressed as number of amino acid residues released per mole of B-casein. ${ }^{3}$ Samples were collected from the $24 \mathrm{~h} \mathrm{RP-HPLC}$ profiles (fractions A and B: see text). The amino acids were analysed after $24 \mathrm{~h}$ of $\beta$-casein peptide hydrolysis by the cell-free extracts at $30^{\circ} \mathrm{C}$. $(-)$, absence of free amino acids. Tryptophan was absent in all the samples.

'La nomenclature des souches correspond à celle du tableau I. L'extrait intracellulaire de la souche CIP 103027 était inactivé par la chaleur (100 ${ }^{\circ} \mathrm{C}$, 10 min) puis additionné à la solution de peptides de caséine $\beta .{ }^{2}$ Les acides aminés libres sont exprimés en nombre d'acides aminés libérés par mole de caséine $\beta$. ${ }^{3}$ Les échantillons étaient collectés lors de l'analyse CLHP phase inverse selon les fractions A et B (cf texte). Les acides aminés libres étaient analysés après 24 h d'hydrolyse par les extraits intracellulaires à $30^{\circ} \mathrm{C}$. (-) Absence d'acides aminés libres. L'acide aminé tryptophane était absent de tous les échantillons. 
Although $P$, freudenreichii subsp, freudenreichii CIP103026 possessed a higher degree of hydrolysis than strain $\mathrm{H}(1.66$ vs. $1.27 \mu \mathrm{mol} \mathrm{Met} / \mathrm{mL}$ ), the latter strain released more free amino acids (1344 vs. $596 \mu \mathrm{mol} / \mathrm{L})$.

Considering all the data it appears that Val, Pro, Glx and Lys in fraction A and Ile+Leu in fraction $B$ were released to the greatest extents (table II). However, from the ratio of each amino acid released upon hydrolysis to their frequencies in $\beta$-casein, it was calculated that Ala always had the highest percentage of release (up to 100\% release with CIP103028) followed by either Arg (up to 65\% with CIP103028), Tyr (up to 57\% with CIP103027), or Gly (up to 54\% with CIP103028). The release percentage of proline was low, between $4 \%$ for CNRZ725 and $15 \%$ for CIP103027, that of phenylalanine was higher, between 14 and $31 \%$ for both strains.

\section{DISCUSSION}

As stated by Langsrud et al. [19] propionibacteria seem to be equipped with many of the enzymes necessary to release amino acids and small peptides from casein substrate. In this work, we showed that the dairy propionibacteria are able to hydrolyze $\beta$-casein peptides at $\mathrm{pH} 5.7$ and at $30^{\circ} \mathrm{C}$. As mainly peptides from $\beta$-casein are present in Swiss-type cheese [1,2], our results support the hypothesis that dairy propionibacteria may contribute during the later stages of proteolysis in Emmental ripening. There also appear to be agreement between the present results and those in reports on the prominent amino acids in cheese juice, i.e., glutamic acid, proline, lysine, leucine, valine [32], or, sometimes, phenylalanine in cheese [18].

The proteolytic activity, expressed with tryptic/chymotryptic peptides of $\beta$-casein as substrate, appears to be strongly strain- dependent among the dairy organisms in the genus Propionibacterium. It varied significantly among the four species and even within one species, as highlighted for $P$. freudenreichii strains. This variability exists not only in terms of level of activity but also in terms of nature of released products (peptides and free amino acids). Concerning the amino acids, the strain-dependent variability could also be the result of proteolysis and further degradation (including deamination, transamination, decarboxylation) which has been very little studied in propionibacteria. Brendehaug and Langsrud [7] showed that suspension of resting cells of two $P$. freudenreichii subsp. shermanii strains led to the total degradation of Asp, Ser, Gly and Ala and a lower or even no degradation of the other amino acids under aerobic conditions. This could explain the absence of some of these amino acids (Ser and Asp) found in our study. Concerning more particularly the free amino acid Asp, its absence in almost all the strains studied, might be due to an aspartase activity, which has been found in propionibacteria [18] and to the fact that Asp is the only amino acid metabolised by $P$. freudenreichii subsp. shermanii in a Swiss cheese environment according to Crow [9]. However, it implies the release of $\mathrm{NH}_{3}$ which was not found in this study. On the other hand, to our knowledge, neither decarboxylase(s) have yet been reported in propionibacteria nor aminotranferase(s) specific for aromatic residues, which have recently been evidenced and characterized in lactococci $[14,36]$.

The amounts of total proline and glutamic acid include intracellular contents which were not negligible in $P$. freudenreichii subsp. shermanii CIP103027 strain (approximately 3 and 2.2 amino acid residues, respectively), and consequently their release is low. With regard to proline, such a low release from the tryptic/chymotryptic $\beta$-casein peptides can be attributed to its 
central or ante-penultimate position in the peptide sequences [26], which perhaps should require previous proteolysis by other aminopeptidases for being released by the very specific enzyme activities already shown in propionibacteria (proline iminopeptidase [25,27], prolinase and prolidase [29]), and X-prolyl dipeptidyl aminopeptidase [13]).

From our results, it can also be hypothesized that the sweet taste generally attributed to proline in Swiss type cheese may also be generated by the mixture of other sweet amino acids such as Gly, Ala, Ser and Thr [18], the release of which was effectively observed in this study.

Diversity in the proteolytic activity of the propionibacteria strains has already been observed but only for a few of them and by using amino acid $\beta$-naphthylamide derivatives, and specific dipeptides, tripeptides and oligopeptides $[10-13,27,31$, 35]. Amino acid $\beta$-naphthylamides are of course not natural substrates whereas selected di-, tri- and oligopeptides may represent some of the peptides in cheese.

From the obtained results, a multiple criteria distinction of strains with extreme characteristics can be proposed in order to check their respective effect on cheese flavor and texture. For example, it could be interesting to compare $P$. jensenii TL222 which had the lowest proteolytic activity in terms of degree of hydrolysis and amino acid release with either $P$. freudenreichii subsp. shermanii CIP103027 which had the highest or $P$. jensenii CIP103028 shown with a low degree of hydrolysis but a high activity for release of Tyr, Arg, Gly and Ala.

Such cheese experiments should be conducted first with the mini-Emmental cheese methodology [8] and then scaled up. According to the so-obtained results on cheese, a strain selection could be developed using as substrate the tryptic/chymotryptic $\beta$-casein hydrolysate and as criteria the degree of hydrolysis at $24 \mathrm{~h}$ with the amount and the nature of the free amino acids released by cell-free extracts. Such a selection will evidently require well-equipped laboratories, but it will give useful data for the cheesemakers, especially if characterization of autolytic ability in cheese environment is determined in parallel.

The results obtained in this study confirm indirectly the presence of intracellular endopeptidase(s) reported by Pripp et al. [28] and Tobiassen et al. [34], which could play a major role in the hydrolysis of hydrophobic peptides as shown in figure 2 . Further work is nevertheless required before attributing the very rare frequency of bitterness defect in hard cooked cheese to enzymes released by autolysis of either propionibacteria or thermophilic lactic starters. However, recent studies showed that the proteolytic activities of lactic acid bacteria and propionibacteria could be complementary $[16,35]$. Therefore, the determination of the respective action of the enzymes from both flora, which is likely sequential during Emmental ripening, appears to be crucial to control Swiss-type cheese ripening.

On the other hand, the release of phenylalanine observed at level up to $20 \%$ of the content in the $\beta$-casein peptides used leads to hypothesize a possible presence in the propionibacteria cell-free extracts of a carboxypeptidase. Indeed, because of the specificity of chymotrypsin [26], Phe has a $\mathrm{C}$-terminal location in the chymotryptic peptides of $\beta$-casein, however, release of Phe may also result from a combined and sequential action of several peptidases.

\section{ACKNOWLEDGMENTS}

This work was supported in part by grants from Standa-Industrie, We thank S. Lortal for helpful discussions and critical reading of the manuscript, and E. Roussel for his constant interest in this work. 


\section{REFERENCES}

[1] Addeo F., Chianese L., Salzano A., Sacchi R., Cappuccio U., Ferranti P., Malorni A., Characterization of the $12 \%$ trichloroacetic acid insoluble oligopeptides of ParmigianoRegiano cheese, J. Dairy Res. 59 (1992) 401-411.

[2] Addeo F., Chianese L., Sacchi R., Spagna Musso S., Ferranti P., Malorni A., Characterization of the oligopeptides of ParmigianoRegiano cheese soluble in $120 \mathrm{~g}$ trichloroacetic acid/l, J. Dairy Res. 61 (1994) 365-374.

[3] Antila V., Antila M., Der Gehait des finnischen Käses an freien Aminosäuren, Milchwissenschaft 23 (1968) 597-602.

[4] Bergère J.L., Accolas J.P., Non sporing and sporing anaerobes in dairy products, in: Barnes E.M., Mead G.C. (Eds.), Anaerobic bacteria in habitats other than man. The Society for Applied Bacteriology Symposium Series No. 13, Blackwell Scientific Publications, Oxford, 1986, pp. 373-396.

[5] Bidlingmeyer B.A., Cohen S.A., Tarvin T.L., Rapid analysis of amino acids using precolumn derivatization, J. Chromatogr. 336 (1984) 93-104.

[6] Biede S.L., Hammond E.G., Swiss cheese flavor: I. Chemical analysis; II. Organoleptic analysis, J. Dairy Sci. 62 (1979) 227-248.

[7] Brendehaug J., Langsrud T., Amino acid metabolism in propionibacteria: resting cells experiments with four strains, J. Dairy Sci 68 (1985) 281-289.

[8] Buisson V., Kerjean J.R., Courroye M., Miniaturisation de la fabrication fromagère. Un nouveau test pour mesurer l'aptitude fromagère des laits, Tech. Lait 1024 (1987) 17-23.

[9] Crow V.L., Metabolism of aspartate by Propionibacterium freudenreichii subsp. shermanii: effect on lactate fermentation, Appl. Environ. Microbiol. 52 (1986) 359-365.

[10] Dupuis C., Activités protéolytiques et lipolytiques des bactéries propioniques laitières. $\mathrm{Ph}$. D. thesis. Université de Rennes, France, 1994.

[11] El Soda M., Macedo A., Olson N.F., Aminopeptidase and dipeptidylaminopeptidase activities of several cheese-related microorganisms, Milchwissenschaft 46 (1991) 223-226.

[12] El Soda M., Ziada N., Ezzat N., The intracellular peptide-hydrolase system of Propionibacterium, Microbios 72 (1992) 65-74.

[13] Fernandez-Espla M.D., Fox P.F., Purification and characterization of X-Prolyl dipeptidyl aminopeptidase from propionibacterium sher- manii NCDO 853, Int. Dairy J. 7 (1997) 23-29.

[14] Gao D.H.O., Broadbent J.R., Johnson M.E., Weimer B.C., Steele J.L., Aromatic amino acid catabolism by lactococci, Lait 77 (1997) $371-381$.

[15] Ghuysen J.M., Tipper D.J., Strominger J.L., Enzymes that degrade bacterial cell walls, Methods Enzymol. 8 (1966) 694-696.

[16] Gobbetti M., Stepaniak L., Fox P.F., Sorhaug T., Tobiassen R., Inhibition of endo- and aminopeptidase activities in cytoplasmic fractions of Lactococcus, Lactobacillus and Propionibacterium by peptides of different cheeses, Milchwissenschaft 50 (1995) 565-570.

[17] Griffith R., Hammond E.G., Generation of Swiss cheese flavor components by the reaction of amino acids with carbonyl compounds, J. Dairy Sci. 72 (1989) 604-613.

[18] Langsrud T., Reinbold G.W., Flavor development and microbiology of Swiss cheese-A review. III. Ripening and flavor production, J. Milk Food Technol. 36 (1973) 593-609.

[19] Langsrud T., Sorhaug T., Vegarud G., Protein degradation and amino acid metabolism by propionibacteria, Lait 75 (1995) 325-330.

[20] Lemée R., Rouault A., Guézenec S., Lortal S., Autolysis of fifty seven strains of dairy propionibacteria, Lait 74 (1994) 241-251.

[2I] Lemée R., Lortal S., Cesselin B., van Heijenoort J., Involvement of an $\mathrm{N}$-acetylglucosaminidase in autolysis of Propionibacterium freudenreichii CNRZ 725, Appl. Environ. Microbiol. 60 (1994) 4351-4358.

[22] Malik A.C., Reinbold G.W., Vedamuthu E.R., Evaluation of the taxonomy of Propionibacterium, Can. J. Microbiol. 14 (1968) 1185-1191.

[23] Østlie H., Floberghagen V., Reinbold G.W., Hammond E.G., Vegarud G., Langsrud T., Autolysis of dairy propionibacteria: growth studies, peptidase activities, and proline production, J. Dairy Sci. 78 (1995) 1224-1237.

[24] Østlie H., Vegarud G., Langsrud T., Autolysis of dairy propionibacteria in buffer systems, J. Dairy Sci. 78 (1995) 2315-2325.

[25] Panon G., Purification and characterization of a proline iminopeptidase from Propionibacterium shermanii 13673, Lait 70 (1990) $439-452$.

[26] Pélissier J.-P., Protéolyse des caséines, Sci. Aliments 4 (1984) 1-35.

[27] Perez Chaia A., Pesce de Ruiz Holgado A. Oliver G., Peptide hydrolases of propionibacteria: effect of $\mathrm{pH}$ and temperature, J. Food Prot. 53 (1990) 237-240. 
[28] Pripp A.H., Tobiassen R.O., Stepaniak L., Sørhaug T., Endopeptidases and aminopeptidases from Propionibacterium freudenreichii ATCC 9614. Distribution and partial separation of intracellular fraction, in: Conferences and posters abstracts of the First International Symposium on Dairy Propionibacteria, Inra, Rennes, France, 66, 1995.

[29] Quelen L.C., Dupuis C., Boyaval P., Prolinespecific activities of $P$. freudenreichii subsp. shermanii, J. Dairy Res. 62 (1995) 661-666.

[30] Rolin D.B., Girard J.D., de Certaines J.D., Boyaval P., ${ }^{13} \mathrm{C}-\mathrm{NMR}$ study of lactate metabolism in Propionibacterium freudenreichii subsp. shermanii, Appl. Microbiol. Biotechnol. 44 (1995) 210-217.

[31] Sahlström S., Espinosa C., Langsrud T., Sørhaug T., Cell wall, membrane, and intracellular peptidase activities of Propionibacterium shermanii, J. Dairy Sci. 72 (1989) 342-350.

[32] Salvat-Brunaud D, Maubois JL, Le Graët Y, Piot M, Maillard MB, Corre C, Thierry A. (1995) Extraction et analyse de la phase aqueuse de l'Emmental à 4 stades d'affinage, Lait 75, 239-249.
[33] Steffen C., Eberhard P., Bosset J.O., Rüegg M., Biochemistry of cheese ripening, in: Fox P.F. (Ed.), Cheese: chemistry, physics and microbiology, Vol. 2, Major cheese groups, Chapman \& Hall, London, 1993, pp. 83-110.

[34] Tobiassen R.O., Pripp A.H., Stepaniak L., Sletten K., Sørhaug T., Purification and characterization of an endopeptidase from Propionibacterium freudenreichii, J. Dairy Sci. 79 (1996) 2129-2136.

[35] Tobiassen R.O., Stepaniak L., Sørhaug T., Screening for differences in the proteolytic systems of Lactococcus, Lactobacillus and Propionibacterium, Z. Lebensm. Forschung 204 (1997) 273-278.

[36] Yvon M., Thirouin S., Rijnen L., Fromentier D., Gripon J.C,,, An aminotransferase from Lactococcus lactis initiates conversion of amino acids to cheese flavor compounds, Appl. Environ. Microbiol. 63 (1997) 414-419. 